\section{Research Article}

(c) 2021 T. L. Malatji.

This is an open access article licensed under the Creative Commons Attribution-NonCommercial 4.o International License

(https://creativecommons.org/licenses/by-nc/4.o/)

\title{
Inaccessibility of Market Information and Finances, an Impediment to the Success of Emerging Black Farmers in Tzaneen Municipality, Limpopo Province
}

\author{
T. L. Malatji \\ University of Limpopo, \\ Polokwane, 0727, South Africa
}

DOI: https://doi.org/10.36941/ajis-2021-0o63

\begin{abstract}
This study investigated how lack of access to market and lack of finances pose an obstacle to the success of emerging farmers. The aim of the study is to determine/examine factors that lead to the failure of emerging farmers in their farming business. Most of the farmers struggle to not cut their trade into commercial farming due to unavailability of information on market access and finances. The author sampled 16 emerging farmers from Mopani District to partake in this study. Findings from the study showed that emerging farmers had difficulties competing in the market owing to limited or no access to information about market prices, the type and quality of produce expected for the target market needs. Only a few of these farmers can conduct market research, and this leads to a situation where the majority will have to rely on those few for information. Moreover, the difficulties of accessing (credit facilities) funds from financial institutions are also highlighted in the study. Nonetheless, it is without any doubt that emerging farmers do not have same advantages as compared to well established companies. Lack of access to market information and credit facilities has a negative impact on the production of the farmers. However, most of them continue to produce for the locals and their household consumption.
\end{abstract}

Keywords: Emerging Farmers, Market, Information, Produce, Prices, Finances

\section{Introduction}

All emerging farmers have aspirations of tapping into commercial farming and supply a broader market on a local, national and an international scale, to ultimately contribute to the Gross Domestic Product (GDP) of the country as well as create jobs and improve the quality of life for many people. The emerging farmers in South Africa originate from the group of smallholder farmers, who were previously excluded from the mainstream economy. They now constitute a major part of what is referred to as the second economy in agriculture. They include beneficiaries of land reform programmes like Proactive Land Acquisition Strategy (PLAS) which the government of South Africa introduced to fastrack the land reform programmes (Senyolo, Chaminuka, Makhura and Belete, 2009).

This paper seeks to outline the challenges which the black emerging farmers experience in their farming businesses and how lack of funding and information can negatively affect their farming business. Majority of this emerging black farmers are left frustrated because they rely on black market and they do not make any income that will help sustain their businesses. 
Poor emerging farmers in South Africa attribute their low living standards to numerous challenges, such as barrier of market entry. They generate different agricultural produce but do not know where to sell their produce and grow their supplies, and this frustrates the farmers (Magingxa and Kamara, 2003; Heinemann, 2002). Lack of access to information about the market can destroy the farmers because they do not have the experience and are just negotiating their way into the farming business. The emerging farmers have the potential to grow their farms and better their lives, their families, and the people they employ. However, they continue to face impediments like lack of information about the market including market prices, demand, and supply chain as well as the market price. Moreover, their competitive edge is marginal because they do not have information about their competitors (Magingxa, and Kamara, 2003).

Access to information related to the market is crucial for the growth and development of emerging farmers. This will make the demand to be high and in turn offers remunerative prices; which results in increasing the farmers' income and their farming business prospects. Another factor confronting emerging farmers is finances, which they need for operation and to sustain their farms. Without financial muscles, emerging farmers will not make it into commercial farming (Sebola, 2018; Mageza and Michael, 2014).

\section{Literature Review}

\subsection{Lack of Access to Agricultural Market as an Obstacle to Emerging Farmers}

Nxumalo, Antwi and Rhubara (2020) argued that there are lots of emerging black farmers in South Africa who are still struggling to make it into the commercial farming due to lack of access to adequate market facilities, high labour-intensity, low farm capital investment, and no adequate support from the government (Chauke, Motlhatlhana, Pfumayaramba and Anim, 2013).

Access to markets is important to the growth of all categories of producers, and the limited access to agricultural markets among emerging black farmers especially in the rural areas represent a key challenge. An improved access to markets by emerging farmers helps with the transformation of from subsistence to commercial farming, which is exactly what the black farmers in South Africa seeks. Lack of access to the market by the emerging farmers pose a serious threat and it deny the smallholder farmers beneficial effects from agricultural growth. However, this means that the emerging black farmers will not achieve their dream of becoming competitive commercial farmers and contribute to the economic growth of the country (Nwafor, 2020).

Magingxa and Kamara (2003) consider emerging farmers who live in rural areas all over Africa, especially the poor, advocating that their main setback in improving their standard of living are difficulties of accessing the market. Although they can obtain agricultural inputs and consumer goods while selling their products which they grow themselves, because of a lack of access to market, the majority of the black emerging farmers are still struggling even if they produce high quantity of produce, but they have got no enough market to take their produce and remain in poverty. Moreover, this is difficult for the farmers because they end up selling their produce with prices dictated by the consumer or buyer.

Gaanakgomo (2015, Sikwela and Mushunje, 2013) acknowledge that market information plays a critical role to the success of the emerging black farmers and it influence marketing channel choices among emerging farmers. This will also provide knowledge on the type and quantity of produce required in the market, their quality, and the price at which they will be sold, and the demand of the produce. When the market information is easily accessible, it allows emerging farmers an opportunity to comply with retailers' standards, to compete with commercial farmers and produce the desired quality and quantity of products because they have access to the necessary and relevant market knowledge.

Some of the local farmers sell their products through informal channels like neighbours and local shops (Ortmann \& King, 2007). The market usually favours well-established farmers who can ensure 
high volumes, are consistent and can supply their produce and sustain it in the long run. This criterion works for the capitalised commercial sector and disadvantages emerging farmers. The emerging farmers are excluded from the mainstream of agricultural economy as dominant supermarkets and processors prefer suppliers who can consistently deliver quality goods over a long-term contract (Louw, Vermuelen \& Madevu, 2006).

Antwi and Seahlodi (2011) acknowledge that emerging farmers complain about the issue of a lack of information as one of the constraints they face. A high percentage of the South African population lives in the rural areas and dissemination of information to the rural community members is often poor. In many respects, rural farmers are of the view that there are no communication channels used to receive information about the prices of the agricultural produce, lacking access to the existing highvalue market.

Magingxa and Kamara (2003) indicate that emerging farmers in their dealings with the market participants, traders, buyers happen to find themselves at a major disadvantage. Majority of them find it difficult to understand how the market functions and why prices fluctuate. They do not have enough information and knowledge in terms of market conditions and prices. Hence, the farmers do not have a formal forum where they can collectively discuss some of the issues, and they don't have experience of market negotiation which is very important aspect when it comes to marketing of the products produced by farmers (Freeman and Silim, 2001; Heinemann, 2002).

However, the issue of information exchange about the market remains a constrain to the farmers. Producers experience a weak bargaining position vis-à-vis traders because often they do not have timely access to salient and accurate information on current prices, locations of effective demand, preferred quality characteristics of horticultural produce, and alternative marketing channels. The problem of market access is linked to the following constraints: price risk and uncertainty, difficulties of contract enforcement, insufficient numbers of middlemen, cost of putting small dispersed quantities of produce together, and inability to meet standards. Other compounding problems relate to physical market access like physical infrastructure - roads, market facilities, power and electricity. There is no adequate support system available to emerging farmers (Khapayi and Ceiliers, 2016; Magingxa and Kamara, 2003).

\section{The Importance of Access to Market and Development of Emerging Farmers}

Emerging farmers should access agricultural market information because it is an important aspect of agricultural development. The use of accurate and timely agricultural market information by the farmers improves market performance and the knowledge of all market actors. It is the dream of every emerging farmer to become a commercial farmer; however, without access to the market, their dreams are drifting planets away from reality as their produce will never reach the market. Moreover, the availability of information will play a critical role in their development (Magesa, Michael and Ko, 2014). The information that is available to emerging farmers in rural areas may not be equally distributed because the majority of them are in remote communities. This disadvantage serves to further distances the farmers from the market. The other contributing factor to their lack of access to up-to-date market information is that the majority of emerging farmers still rely on secondary information sources provided by other farmers since they cannot use technology to search for and gather necessary information (Magingxa and Kamara, 2003).

The agricultural market plays an important role in farm households who act as both sellers and buyers of food and other agricultural commodities. There are different types of markets, namely small local village markets and larger district markets. The local markets are relevant for sales and purchases of smaller quantities of goods which are produced by local farmers, to satisfy immediate needs. This kind of markets are easily accessible by the communities and the products are traded at a low price because there are no transportation costs. However, the local markets also play an important role for fresh fruits, vegetables and dairy products that cannot be stored for longer periods (Koppmair, Kassie and Qaim, 2017). 
Continued participation in the market is important amongst smallholder and emerging farmers because they may derive benefits such employment opportunities and income. In this way, the rural smallholder producers of agricultural products will be effectively integrated into the mainstream economies. Access to the market does not only benefit the farmers but also the poor households in terms of employment. When farmers can produce and supply the market, they do not only surpass break-even but also create jobs for the needy in their regions. The less-developed rural economies in South Africa and smallholder farmers grapple with access to commercial markets on many fronts given persisting technical and institutional constraints. Such constraints include poor infrastructure, lack of market transport, a dearth of market information, insufficient expertise on grades and standards, inability to have contractual agreements, and poor organisational support. These have led to the inefficient use of markets; hence, commercialisation bottlenecks (Jari and Fraser, 2009; Obi and Pote, 2012).

\section{Difficulties in Securing Finances from Financial Institutions}

Lack of capital for emerging farmers or small businesses is another major constraint for rural development. Emerging farmers rely on borrowing money from friends, family and rural or township lenders in order to meet their financial obligations. The commercial banks are hesitant to lend money to emerging farmers due to the high risks associated with the lending of funds to small businesses (Ortmann \& King, 2007).

According to Greenberg (2010), during the Apartheid era, it was easier for the farmers to borrow money from the government through parastatals. The interest rates were low and affordable. The Land Bank, Agricultural Credit Board (ACB) and cooperatives were actively involved in the financing of the farmers. The cooperatives used to play a much bigger role when coming to the storage of the crops for future use, and that made it easier for the farmers to continue with their businesses. Contrariwise, the cooperatives are no longer effective, and it is not easy to store crops or any produce. Jera and Ajayi (2008) point out that in Africa there are a large number of smallholder farmers who are involved in livestock production as part of their farming system.

According to Sebola (2018), the models for funding emerging farmers in South Africa are known to be categorised into two types - loan funding and grant funding. However, there is a major problem in both funding models because of the failure of South African policymakers to measure the effectiveness of those models in the sense that from the start they have targeted wrong beneficiaries.

\section{Access to Credit by Emerging Farmers}

Access to credit funding is a common problem for emerging farmers in Africa. The traditional credit institutions have consistently failed to provide small-scale farmers with the necessary financial support. The rural finance systems are regarded as an important mechanism that can be used to overcome the problem of production capital for agricultural development which the emerging farmers are facing. Besides, these rural finance systems include various forms of banking arrangements, cooperatives, mutual benefits societies and solidarity group which are expected to fund the farmers (Sebola, 2018; Cloete, 2013).

Lack of finance to fund operations and farming activities, acquire capital goods and meet working capital requirements has arguably been the largest challenge for most smallholders or emerging farmers in South Africa. This put pressure on the farmers to obtain, get funds elsewhere in order to sustain their farms. The majority of these farmers borrow from loan sharks rather than banks or other financial institutions because they do not qualify for even any small business loan. Poor farmers often have difficulty obtaining credit and financial institutions are typically biased against smallholders, particularly women farmers (Chisasa and Makina, 2012).

According to Sikwela and Mushunje (2013), production from the emerging farmers has declined over the past 10 years and the division that exists between smallholder/emerging and commercial 
farmer productivity levels appears to be growing. This is because of the low level of support provided to these smallholder farmers or resources availed to them. The Department of Agriculture's Integrated Growth and Development Plan states that commercial, smallholder and subsistence farmers in South Africa currently receive less support from the state than their counterparts in any industrialised country in the world. The poor farmers do not get all the financial support they need, and they do not qualify for credit since the majority of them are not employed. Since they do not have any other source of income all they need is government support or a mechanism creation that can help them sustain and develop their businesses.

Giving loans to rural poor farmers is considered a high-risk, high-cost proposition for financial institutions. There are some doubts about the repayment capacity of poor rural borrowers, with their unstable income streams and expenditure patterns. In the absence of credit information, this drives up default risk. This problem is worsened by the borrower's lack of collateral and/or difficulties in contract design and enforcement. Moreover, the transaction costs of rural lending are high, mainly due to small loan sizes, the high frequency of transactions, the large geographical spread of the borrowers, and widespread illiteracy (Basu, 2006).

\section{Methodology}

The methodology is the philosophical framework within which the research is conducted or the foundation upon which the research is based, and the methodology helps in understanding why a particular study is undertaken (Malatji, 2017). A qualitative study was used to gather relevant data through the phenomenological approach. With assistance from the Limpopo Department of Agriculture, the researcher was able to obtain a list of all beneficiaries of PLAS in Mopani District so they all could participate in the study. The study was undertaken in the year 2017 in Tzaneen municipality which is located in Limpopo Province.

\section{Research Design}

\subsection{Target Population}

Most of the respondents in this study were males and two females to comprise a gender mix from 16 respondents. This gender bias aspect of respondents indicate that males are dominant in the emerging farming sector in Mopani District. In terms of age, most of these emerging farmers were above 5o, six of them were between 35 and 50 while only two were below 35 years. Majority of the respondents or emerging farmers in this study are not learned and this contributed to their lack of competition in the farming business.

\subsection{Method of Data Collection}

\subsubsection{Research Instruments}

\subsubsection{Interviews}

The researcher used an interview guide to collect data from emerging farmers. The study relied on linguistic data that was obtained from the source of information. The linguistics data were more reliable and had more confidence level of decision-making with the trusted analysis having direct intact with the occurrence of the events. Research questions were developed and used during the interviews. The questions were drafted in English but during the interviews, the researcher translated the questions in the local languages, which was very easy because the researcher is fluent in those local languages. The researcher needed to translate the instrument into local languages so the respondents could be able to express themselves in the language they understood better. 
Interviewing is a way to collect data as well as to gain knowledge from individuals. It is an interchange of views between two or more people on a topic of mutual interest, sees the centrality of human interaction for knowledge production, and emphasises the social situatedness of research data. Interviews are ways for participants to get involved and talk about their views. Also, the interviewees can discuss their perception and interpretation regarding a given situation. It is their expression from their point of view. Cohen, Manion and Morrison (2000) posit that an interview is not simply concerned with collecting data about life; it is part of life itself and inescapable (Kajornboon, 2005).

Research questions were developed and used during the interviews. The questions were drafted in English but during the interviews, the researcher translated the questions in the local languages, which was very easy because the researcher is fluent in those local languages. Due to that, the respondents could be able to express themselves in the language they understand better.

The general interview guide approach is more structured than the informal conversational interview. Interview guide is important according to McNamara (2009), it serves as the ability of the researcher to ensure that the same general areas of information are collected from each interviewee. This provides more focus than the conversational approach and still allows a degree of freedom and adaptability in getting information from each interviewee. Nonetheless, questions need to be worded so that respondents expound on the research topic. On the other hand, the researcher remains in the driver's seat with this type of interview approach and is in control as the facilitator, but flexibility takes precedence based on perceived prompts from the participants (Turner, 2010; Guion, Diehl and McDonald, 2001).

\subsubsection{Focus Group Discussion}

According to Fatemeh (2004), a focus group is a technique which involves the use of in-depth group interviews in which participants are selected because they are purposive. In this kind of interviews, participants are selected in the sense that they would have something to say on the topic, they have the similar characteristics and would be comfortable talking to the interviewer (Fatemeh 2004).

Kitzinger (1994) defines focus groups as groups which are organised to explore a particular set of issues; it is about the people's views regarding certain fundamental issues. These groups are focused in the sense that they involve some kind of collective activity. Group methods are used within communication research and such methods are also popular in studies designed to explore people's experiences of different services.

Focus group discussions with the beneficiaries were conducted to collect data using a semistructured interview guide. Three focus group discussions with participants were conducted. Based on the location, focus group discussions were conducted as follows: one focus group with emerging farmers from Ba-Phalaborwa Local Municipality with four beneficiaries. The second focus group interviews were conducted with emerging farmers from Tzaneen Local Municipality, with five beneficiaries. The third focus group comprised emerging farmers from Maruleng Municipality, with only two beneficiaries of PLAS the programme.

\subsubsection{Sampling design}

The study used a census sampling method. The census method is applied when the whole population, every unit and everyone is considered when the researcher is collecting data (Malatji, 2017). Therefore, all 16 PLAS beneficiaries were included in the study. The census method was used for it was the most suitable for this kind of study because the population is small.

\subsubsection{Research Question}

Black emerging farmers find it very difficult to use their land effectively and produce food and be able to participate in the economic growth of the country. Lack of participation is due to many reasons and 
one of them being lack of finances, inaccessibility of market information and market prices (Malatji, 2017, Mfuywa, 2012). Black emerging farmers do not get enough support from the government as expected and promised. Moreover, most of the farmers are unemployed and do not have any income, they rely solely on their produce from the farms only if they are able to use the land that has been provided to them by government and sell their produce to the black market since they do not have information about the market.

\section{Data Analysis}

According to Brockopp and Hastings-Tolsman (1995), data analysis is the process of bringing order, structure and meaning to the mass of collected data. It is a time consuming and fascinating process, but it is important when conducting research. In this study, the data collected was analysed by organising it according to themes. This data is collected through the various respondents where the questions were structured in a similar approach to allow for consistency. In this way, a thematic analysis was used to analyse the raw data from two key respondent categories, through focus groups and key informant interviews. Thematic analysis is a method for identifying, analysing, and reporting patterns (themes) within data collected. It minimally organises and describes data set in detail (Braun \& Clarke 2006).

\section{Findings}

\subsection{Accessing agricultural market and information}

Respondents highlighted that they used agents to market their farm produce and that has not yielded the expected result. The government does not assist them to access the market. The agent sends them market information and the farmers send back to the agent information about their farm produce. A respondent indicated that they chose to supply their produce to companies that were close to their farms to save money. This is considered an advantage for this farmer because he saved money for transportation and packaging expenses.

Another respondent indicated that he occasionally used Google search engine on the Internet to obtain market information, but the information was not easily available. The respondent further said it was difficult to penetrate the market due to strict requirements, and the requirements badly affected emerging farmers - the same cannot be said about commercial farmers.

Majority of emerging farmers under PLAS do not have access to the market nor information relevant to trade their produce. It becomes a serious challenge for the farmers to participate in the market because they do not have any information about the market, they do not know the kind of crops in demand, and the right time to sell. According to the data collected, some emerging farmers have enough produce that they can supply a broader market, but they (are not aware), do not have a better understanding of policies and procedures (supply chain) to follow. On a positive note, some of the farmers interviewed can research market prices, but they are few. The rest rely on others for information. The literacy levels of the majority of these emerging farmers are very low and it is hard for them to source information. Some cannot navigate their way around technology.

"If we do not have access to the market, it will be hard for us to migrate from emerging farmers to commercial farmers. We do not want to be emerging farmers forever; we are in farming because we want to be commercial farmers and contribute to food security challenges in the country." (Words of Male farmer who has been doing farming for more than 20 years)

One of the respondents indicated that he has been farming for decades and still struggle to access the market. As such, the government categorises him as an emerging farmer, but he begs to differ given his longevity in the sector. 
"Since we do not have access to the market, we can't take our produce anywhere but to rely on the locals." (said a female farmer who is a beneficiary of Proactive land acquisition strategy).

They sell their produce to the locals because they cannot supply supermarkets as there is already a tight belt of the supply chain in the mainstream market. And those supplying the big stores have information on required quality standards. The emerging farmers end up tailoring their produce for household consumption and local market to keep the cash flowing.

For the government to assist emerging farmers, the first initiative would be creating platforms for information on access to the market. The information will help the emerging farmers know the line of production to augment in order to meet market demands. Relevant information would help the emerging farmers know who exactly they are producing for. When you know the target market, you produce enough with certainty that there is demand and the business would have returns. Having a target market and demand also encourages high levels of productivity. There will be no need to store produce for a long period. Besides, some of the emerging farmers do not have storages. What is the use of storing goods when you don't know where to take them or if they will be taken? Without good storage, producing more will lead to spoilage. It is critically important for emerging farmers to have sustainable support from the government to assist with access to the market. Having access to market means emerging farmers will know when to produce and when to sell.

"When we have access to the market, we will be able to produce in large quantities so that we can make more money." (Words from a male citrus farmer)

When local farms are prosperous, they uplift the standard of living in their environs. Poor households in rural areas will get employed. So, the access is not only about boosting profit margins but heightening production processes that result in increased prospects of rural development in terms of socioeconomic statuses.

\section{Lack of Access to Finances}

When asked about access to financial support, emerging farmers indicated that they could not even approach banks for loans because they are flagged as high-risk borrowers. Without collateral, it is not easy to secure funding, the fear is that the farmers may not be able to pay back the loans. Banks engage in risky lending if the borrower has assets that are pledged in the event of defaulting on repayments, and the loan emerging farmers require is huge and without title deeds of the farms, they can't secure loans. The issue of not having title deeds also contributes to their inability to secure credit from financial institutions. The land they farm on belongs to the Department of Rural Development and Land Reform.

The farmers highlighted that the government is not adequately funding them while the majority are poor and need funds to continue operating. Hence, they resort to loan sharks for loans, but it is not easy to repay the loans because of higher interests rates that informal lenders charge compared to registered financial services providers. This is a fundamental problem for emerging farmers because they do not have enough household income. The majority will not be able to gain access to credit. Lack of access to credit will have a negative impact on production in the farms since it is a primary source of generating streams of revenues through selling the produce in the market. For the farmers to make money they have to produce and sell their produce to generate income.

\section{Conclusion}

Emerging farmers in Mopani District and South Africa at large grapple with access to information about the broader market. This is a serious concern because, without access to market information, emerging farmers are likely to fail. Access to market information allows farmers to sell their produce at a specific 
time and compete with other farmers, especially the commercial ones. Access to agricultural markets and information related to farming remain crucial and involves several sectors. Also, key factors affecting infrastructure such as badly maintained roads in rural areas contribute to mobility challenges for emerging farmers. Good roads and reliable means of less transportation costs and consumers, as a result, get better prices to the markets. Apart from road and transport, the farmers need proper storage facilities to store their produce so they may be able to meet demand. Majority of them do not have storage in their farms. These impeding factors show a bleak future for emerging farmers in rural areas - that migrating from emerging to commercial farming remains rhetoric.

\section{Recommendation}

Agriculture, particularly farming, is a demanding business sector with many associated risks, and the risks cannot be pinned on government alone. Financial institutions like banks must come to the party and assist. When farmers are empowered through financial support from both the public and private sectors, they are likely to contribute meaningfully to the mainstream economy while augmenting rural development. Efficient farmers will use the resources to maximise profits and create much-needed jobs for local people and improve their livelihoods and that of their families. For the sake of the success of the emerging black farmers, the South African government should develop an effective support model to help emerging farmers realise their fullest potential, which is to contribute to the country's agricultural development and food security.

The government should not only assist the emerging black farmers with market but ensure that the black emerging farmers partner with white commercial farmers, so they all participate in the economic growth of the country and address the food security threats and this will help them grow as commercial farmers.

Government should offer some trainings and farming skills to emerging farmers, trainings related to financial management and food production is essential to farmers, so they know what kind of produce are good for the kind of land they use.

\section{References}

Antwi, M. \& Seahlodi, P. (2011). Marketing constraints facing Emerging Small-Scale Pig Farmers in Gauteng Province, South Africa. Department of Agricultural Economics and Extension. North-West University, Mmabatho, South Africa.

Braun, V. \& Clarke, V. (2006). Using thematic analysis in psychology. Journal of Qualitative research in psychology, 3(2),77-101. https://doi.org/Digital Objective Identifier

Basu, P. (2006). Improving access to finance for India's rural poor. The World Bank.

Brockopp, D.Y \& Hastings-Tolsman, M.T. 1995. Fundamentals of Nursing Research. CITY: Jones \& Bartlett learning.

Chauke, P.K., Motlhatlhana, M.L., Pfumayaramba, T.K. and Anim, F.D.K., (2013) Factors influencing access to credit: A case study of smallholder farmers in the Capricorn district of South Africa. African Journal of Agricultural Research, 8(7), pp.582-585.

Chisasa, J. \& Makina, D. (2012). Trends in credit to smallholder farmers in South Africa. International Business \& Economics Research Journal (IBER), 11(7), pp.771-784.

Cloete, P.C. (2013). Institutions and Agricultural Development: the case of the North West Province in South Africa. African Journal of Agricultural Research, 8(27), pp.3495-3504.

Cohen, L., Manion, L. \& Morrison, K. (2000). Research Methods in Education. London: Routledge Falmer.

Fatemeh, R. (2004). Focus group interview and data analysis. Birmingham, University of Central England.

Freeman, H.A. \& Silim, S.S. (2001). Commercialisation of Smallholder Irrigation: The Case of Horticultural crops in Semi-arid Areas of Eastern Kenya. in H. Sally and C.L. Abernethy (eds.) Private Irrigation in Sub-Saharan Africa: Proceedings of Regional Seminar on Private Sector Participation an Irrigation Expansion in subSaharan Africa, 22-26 October, Accra, Ghana. IWMI, FAO and CTA.

Gaanakgomo, T., (2015) Challenges and Opportunities Facing Emerging Farmers in North West Province, South African (Doctoral dissertation, North-West University (South Africa)). 
Heinemann, E. (2002). The Role and Limitations of Producer Associations. European Forum for Rural Development Cooperation. 4 September, Montpellier.

Guion, L.A., Diehl, D.C. \& McDonald, D. (2001). Conducting an in-depth interview. McCarty Hall, FL: University of Florida Cooperative Extension Service, Institute of Food and Agricultural Sciences, EDIS.

Jari, B. \& Fraser, G.C.G. (2009). An analysis of institutional and technical factors influencing agricultural marketing amongst smallholder farmers in the Kat River Valley, Eastern Cape Province, South Africa. African Journal of Agricultural Research, 4(11), pp.1129-1137.

Kajornboon, A.B. (2005). Using interviews as research instruments. E-journal for Research Teachers, 2(1), pp.1-9.

Khapayi, M. \& Celliers, P.R. (2016). Factors limiting and preventing emerging farmers to progress to commercial agricultural farming in the King William's Town area of the Eastern Cape Province, South Africa. South African Journal of Agricultural Extension, 44(1), pp.25-41.

Kitzinger, J. (1994). The methodology of focus groups: The importance of interaction between research participants. Sociology of Health and Illness, 16 (1):103-121.

Koppmair, S., Kassie, M. \& Qaim, M. (2017). Farm production, market access and dietary diversity in Malawi. Public health nutrition, 2o(2), pp.325-335.

Louw, A., Vermuelen, H. \& Madevu, H. (2006). Integrating small- scale fresh producers into the main stream agrofood systems in South Africa: The case of a retailer in Venda and local farmers. Department of Agricultural Economics, Extension and Rural Development. University of Pretoria, Tshwane, South Africa.

Magesa, M.M., Michael, K. \& Ko, J. (2014). Access to agricultural market information by rural farmers in Tanzania.

Magingxa, L.L. \& Kamara, A.B. (2003). Institutional perspectives of enhancing smallholder market access in South Africa (No. 344-2016-15075).

Malatji, T.L. (2017). Challenges in the Implementation of Proactive Land Acquisition Strategy (PLAS) in Mopani District area, Limpopo Province (Masters dissertation).

McNamara, C. (2009). General guidelines for conducting interviews. Online available (accessed o9,04 2020) www.managementhelp.org

Mfuywa, S. O., (2012). Factors affecting the functioning of the Pro-Active Land Acquisition Strategy in the Buffalo City Municipal Area. Master of Public Administration, Nelson Mandela Metropolitan University, South Africa.

Nwafor, C.U., (202) Marketing Constraints among Smallholder Farmers in South Africa: An Overview of Potato Market Outlets in Lusikisiki Township.

Nxumalo, K.K.S., Antwi, M.A. and Rubhara, T., (2020) Determinants of use of Farm Machanization Services in Eemrging farmers, North West Province, South Africa. Journal of Agribusiness and Rural Development, 56(2), pp.221-228.

Obi, A. \& Pote, P. (2012). Technical constraints to market access for crop and livestock farmers in Nkonkobe Municipality, Eastern Cape province. In Unlocking markets to smallholders (pp. 91-112). Wageningen Academic Publishers, Wageningen.

Ortmann, G.F. \& King, R.P. (2007). 'Agricultural cooperatives II: can they facilitate access of small-scale farmers in South Africa to input and product markets?' Agrekon, Vol.46, No.2, pp. 219-244.

Sebola, M.P. (2018). Financing emerging black farmers for agricultural development in South Africa: A wasteful and unworkable model for creating black farmers. TD: The Journal for Transdisciplinary Research in Southern Africa, 14(1), pp.1-7.

Senyolo, G.M., Chaminuka, P., Makhura, M.N. \& Belete, A. (2009). Patterns of access and utilization of output markets by emerging farmers in South Africa: Factor analysis approach. African Journal of Agricultural Research, 4(3), pp.208-214.

Sikwela, M.M. \& Mushunje, A. (2013). The impact of farmer support programmes on household income and sustainability in smallholder production: A case study of the Eastern Cape and KwaZulu Natal farmers, South Africa. African Journal of Agricultural Research, 8(21), pp.2502-2511.

Turner III, D.W. (2010). Qualitative interview design: A practical guide for novice investigators. The qualitative report, 15(3), p.754. 